\title{
Concepts of Labour Status and their Operationalisation in Cross-National Comparative Social Surveys
}

\author{
Jürgen H.P. Hoffmeyer-Zlotnik ${ }^{1}$ and Uwe Warner ${ }^{2}$
}

\begin{abstract}
In the social sciences, the occupation variable is used to derive socioeconomic status and/or occupational prestige. This article describes occupation as an indicator for social status and labor status as an indicator of the respondent's position in the life-cycle. First, we identify variables necessary to measure occupation, employment and the labour force concept from ILO (International Labour Organisation, Geneva). Second, we introduce strategies for harmonizing the underlying social concepts of the measurements in surveys across countries. Third, we present our own instrument to measure occupation and labour status as social demographic background variables in cross-national comparative surveys. Finally, we summarize the findings from a pilot survey. The test revealed that the instrument enables the data needed for the social science analysis of socioeconomic status and occupational prestige to be collected with ease.
\end{abstract}

\section{Preliminary remarks}

In academically driven social science and economic surveys, and in surveys conducted by the national statistical offices, numerous questions are needed in order to capture the thematic complex 'socio-economic status'. On the one hand, the respondent's 'labour force status' is of interest: is the person economically active or not? And, if not, what alternative labour force status category applies? On the other hand, information on the respondent's occupational activity is required. Indeed, this is the main information that social scientists use to assess the respondent's socio-economic status. The occupational activity that a person pursues confers a certain amount of social prestige. And, as most jobs call for a

\footnotetext{
${ }^{1}$ GESIS - Leibniz Institute for the Social Sciences, Mannheim, Germany.

${ }^{2}$ CEPS/INSTEAD - Centre d'Etudes de Populations, de Pauvreté et de Politiques SocioEconomiques / International Network for Studies in Technology, Environment, Alternatives, Development, Esch/Alzette, Luxembourg.
} 
certain level of education and training and allow the incumbent to expect a certain standard income ${ }^{3}$, occupation is also the key variable used to determine respondents' social status.

For social scientists, the measurement of occupational activity is relatively uncontroversial. In the social sciences, and especially in cross-national comparative surveys, this variable is measured in such a way that the occupation can be coded into the International Standard Classification of Occupations (ISCO) (ILO 1990; 2008). The ISCO occupation codes (1988 version, ILO 1990) can, in turn, be mapped into the Standard International Occupational Prestige Scale (SIOPS) (Treiman 1977) and the International Socio-Economic Index of Occupational Status (ISEI) (Ganzeboom, De Graaf, Treiman, and de Leeuw 1992; Ganzeboom and Treiman 1996) ${ }^{4}$. The national statistical offices of the individual states frequently employ national instruments that also serve to monitor and describe the national labour market. These national instruments cannot be used for cross-national comparison purposes. However, Eurostat, the statistical office of the European Union, requires that national data be coded into ISCO ${ }^{5}$.

The measurement of labour status is more problematical, and social science surveys diverge considerably from surveys conducted by the national statistical offices in this regard. Eurostat requires that national statistical offices measure labour status and economic activity in accordance with the International Labour Organization's (ILO) labour force concept (European Commission 2009). Whereas the labour status data collected by national statistical agencies are needed to prepare national accounts (European System of Accounts, ESA95), social science researchers use them to determine socio-economic status. From the social science perspective, the occupation a person pursues confers a certain level of prestige and assigns the incumbent a rank in the social stratification system.

In this paper, we first outline the assumptions on which the assignment of an appropriate socio-economic status to a person or household is based. Then we explain why the ILO's labour force concept is of little help in this regard. And finally, we ask what form a survey instrument suitable for comparative social science research must take, bearing in mind that the national statistical offices supply the reference data for social research.

\footnotetext{
${ }^{3}$ - even though there is no longer a clear causal relationship between jobs and level of remuneration.

${ }^{4}$ Other possibilities to relate ISCO codes to social classes and stratification concepts are described in Leiulfsrud, Bison, and Solheim 2010.

${ }^{5}$ At present, national statistical offices and social researchers are still using the ISCO-1988 version because the latest update, ISCO-08, is available only as a 'final draft', and the conversion tables for mapping national occupation codes into ISCO-08 and ISCO-08 codes into SIOPS and ISEI have yet to be developed.
} 


\section{Social status and occupational prestige}

The assignment of social status and/or occupational prestige on the basis of occupational activity is based on a number of assumptions. Occupation has long been regarded as a social background variable (Duncan 1961). This view stems from the implicit assumption that, in a society characterised by the division of labour, a person's social position is determined mainly by the occupation he or she pursues. Education and income are closely correlated with the occupation variable. The importance of occupation and professional position is attributed to the fact that they are regarded as important determinants of lifestyle, behaviour, attitudes, and group behaviour (Mayer 1979: 81). Socio-economic status scales reflect the assumption that a particular occupation calls for a certain level of education and guarantees an income within a certain range. The socio-economic status scales from Duncan (1961) through Nam and Powers (1983), Ganzeboom, De Graaf, Treiman, and de Leeuw (1992), and Hauser and Warren (1997) to Ganzeboom and Treiman (2003) and Nam and Boyd (2004) are based on this logic. Although the various scales feature minor, but methodologically significant, differences, they all consider the occupational description to be the key variable. This occupational description presupposes that the temporal extent of the occupational activity (i.e. the number of hours worked) is such that the job is of relevance when it comes to determining the person's socio-economic status. Status assignment on the basis of occupational activity is possible only if the person works a substantial number of hours in one job. Hence, it is important that the occupational activity that determines the socio-economic status of the respondent be measured as precisely and comprehensively as possible in the survey.

However, occupation also has a subjective component: prestige. Occupations are ranked according to their contribution to the functioning of society or according to a collective perception of the value and standing of the job in question. North and Hatt (1947) studied age, education and income in relation to the prestige of occupations. Their pioneering research was followed in the 1960s by a series of studies that led to occupational prestige being linked to socioeconomic status. The resulting scale for the measurement of occupational prestige, which is still valid today, was developed by Treiman (1977). The current version is known as the Standard International Occupational Prestige Scale (SIOPS) (see Ganzeboom, De Graaf, Treiman, and de Leeuw 1992). In 1996, Ganzeboom and Treiman supplemented SIOPS with a further social science instrument, the International Socio-Economic Index of Occupational Status (ISEI), which is based on additional assumptions regarding prerequisite education and expected remuneration (see Ganzeboom and Treiman 2003). 


\section{Labour status}

Labour status distinguishes between persons who are economically active and those who are not.

1) Economically active persons are

a) available for work and pursue a job or

b) temporarily absent from that job (on leave for the purpose of child care, on a sabbatical etc.) or

c) seeking a job.

2) Economically inactive persons

a) are still in the education or training stage and, thus, not yet part of the workforce, or

b) already in the retirement phase that follows the economically active phase.

Also included in the economically inactive category are

c) all those who, for whatever reason, are not or are no longer available to the labour market although they are capable of working. These include persons engaged in activities such as child care, care of incapacitated relatives or household members, and domestic tasks.

d) persons who are incapable of working due to chronic illness or physical or mental disability.

A definition of labour status that is relevant to the social sciences can take as its starting point the European System of Accounts' (ESA95) definition of employed persons as "... all persons - both employees and self-employed engaged in some productive activity that falls within the production boundary of the system" (European Commission, Eurostat 1995: 465). However, in the social sciences the concept of employment must be defined in such a way that conclusions can be drawn about the socio-economic status of the respondent.

A second starting point is the concept of economical activity that covers any work for pay, profit or family gain for at least one hour during the reference week of the survey.

The relevant question for a sociological interpretation of labour status is not whether a person is economically active at all, but rather what temporal extent a job must have if it is to determine the individual's social status. In a macroeconomic context, the temporal extent of an occupational activity ranges from casual employment or employment on an hourly basis to full-time employment. As a rule, 'full-time employment' is based on the volume of work that is deemed either by collective agreement or general consensus (for example in the case of self-employed persons or farmers) to be a full working day in the respective sector in the country in question. We define part-time employment as working time that is less than a full working day but not less than half a working 
day, and we classify as 'marginal employment' all economic activities that amount to less than half a working day (irrespective of whether the person pursues just one job or several mini-jobs).

Only an occupational activity that is extensive enough to dominate the individual's daily routine can be regarded as determining his or her social status. This is the case with full-time and substantial part-time jobs, irrespective of whether the person is an employee, self-employed, or a contributing family worker. In all other cases, the current labour status of the individual must be determined because marginal employment does not generally determine social status - even though it can influence it. If the target person is not of working age, then he or she is either in the learning stage or in retirement. If the respondent is of working age, and if the current labour status is temporary, then the last full- or part-time job pursued can be recorded. This job can serve to determine the person's status because a situation that is merely temporary will not fundamentally alter the person's social standing. However, if the current situation is not merely a temporary interruption in employment, the appropriate labour status category must be given and the social status of the respondent must be determined on the basis of other data.

\section{The influence of the ILO labour force concept on social science surveys and surveys conducted by national statistical offices}

The labour force concept (ILO 1982; Hussmans, Mehran, and Verma 1990; Rengers 2004) groups together all members of the 'economically active population' who contribute to the supply of labour for the production of goods and services. Work for pay, profit or family gain is viewed here from an economic perspective as a factor of production. Details of the volume of work available and on offer are needed in order to draw inferences about Gross National Income (GNI).

The ILO concept divides the economically active population into the 'usually active population' (ILO 1982: 2) and the 'currently active population' (ILO 1982: 2 ). The 'usually active population' comprises those who have been economically active at some time during a long reference period, for example 'the last twelve months'. The 'currently active population', on the other hand, are those persons who were economically active during a short reference period, such as 'the past week (from Monday to Sunday)'. Surveys focus on the 'currently active population'. According to the ILO concept, a person is economically active if he or she contributes - or is available to contribute - to the production of goods or services that fall within the United Nations (1993) System of National Accounts (SNA) boundary. For the one-week reference period, the concept of 'some work' is defined as 'at least one hour' (ILO 1982: 4). 
A closer look at the definition reveals six superordinate groups of persons: (a) the employed, (b) the unemployed, (c) the population not economically active, (d) the population not usually active, (e) conscripts in compulsory military or community service, and (f) all those persons who are outside the age limits, i.e. under 15 (in some countries 16) or over 74 years of age.

The 'employed' group comprises persons in the following categories (ILO 1982: 3f.):

1) 'paid employment':

- ' 'at work' - persons who performed some work for wage or salary, in cash or in kind, during the reference period, or

- 'with a job but not at work' - persons who have already worked in their present job but who were temporarily absent from work during the reference period. Possible reasons for their absence include illness, vacation, strike, training course/further education, maternity leave, reduction in working time, short-time working, or temporary suspension of operations due to a shortage of raw materials.

2) 'self-employment':

- also broken down into 'at work' and 'with a job but not at work'. The latter are persons who are working in production, agriculture or services and who were temporarily absent from work during the reference period.

- persons who produce goods and services for their own consumption are included in the 'self-employed' category provided production accounts for a significant share of the total consumption of the household.

- The self-employed also include unpaid contributing family workers.

Students, housewives/homemakers who were mainly 'not economically active', but who, at the same time, did some work in an employed or self-employed capacity should be assigned either to the 'paid employment' or the 'selfemployment' category, as the case may be.

The 'unemployed' group includes all persons between the ages of 15 (in some countries 16) and 75 who do not belong to the 'employed' group and who satisfy the following three criteria (ILO 1982: 4):

1) 'without work', i.e. neither in paid employment nor self-employed but available for work (paid employment or self-employed) during the reference week

2) actively seeking work, and

3) able to take up a job offer in the short term.

The 'population not economically active' (ILO 1982: 5) includes persons of working age (between 15/16 and 75) who were neither 'employed' nor 'unemployed' during the reference week because they were either a) attending a 
general education school, b) engaged in domestic activities, c) retired, or d) not currently economically active for reasons such as infirmity or incapacity for work.

A fourth group comprises 'the population not usually active' (ILO 1982: 5). This group includes all persons who belong neither to the 'employed' nor to the 'unemployed' group, i.e.

- students

- housewives / homemakers, persons caring for family members

- pensioners and rentiers

- other persons who live on public or private transfer payments

- persons who work only on a voluntary basis or who work less than the one hour per week limit.

Because national statistical offices are interested in the economic aspect of employment, they determine who contributes - or could contribute - to Gross National Income (GNI). The European Commission ESA directive (European Commission, Eurostat, 1995) obliges all EU member states to survey employment according to the ILO labour force concept. Although the ILO (1982) has issued precise definitions of the variables and categories, each member state interprets and collects the necessary information in its own idiosyncratic way (HoffmeyerZlotnik and Warner 2011: 23ff. and Appendix).

The groups defined above represent economic groups rather than homogeneous population groups whose members are characterised by one socio-economic status. For a sociological analysis, the division of 'employed persons' into persons 'at work' and those 'with a job but not at work' is not of relevance. What is, however, important is a differentiation according to the temporal extent of the job in question. This is because only a job that exceeds a certain minimum number of hours can characterise a person in terms of prestige and status. The socioeconomic status of marginally employed persons is not determined by their jobs but rather by other personal or household variables. Hence, surveys must first sort 'employed persons' according to the extent and type of employment pursued. Only then is it possible to assign the respondent to a status group on the basis of the description of his or her occupational activity.

\section{$5 \quad$ Key elements of a social science survey}

The best way to map 'occupation' into socio-economic status is via the International Standard Classification of Occupations (ISCO).

To do so, labour status must first be measured by asking: Is the person economically active? And, if not, what is his or her status (for example, undergoing vocational training, homemaker, engaged in child care, in retirement)? If the respondent is economically active, his or her professional status (employed, 
self-employed, contributing family worker) and occupational status (prestige) must be clarified. What is important is that all aspects relating to the employment situation and all alternative positions in the life cycle be measured. Hence, it is essential to go beyond the ILO labour force concept and to determine with just a few questions whether the target person's current economic activity suffices to define his or her socio-economic status. Moreover, it is important to find out whether the respondent is the household member who determines the status of the entire household. As a rule, general population surveys select only one reference person per household. This person is supposed to provide information on the entire household. In households comprising more than one person, the reference person constitutes, at best, half the residents of the household. ${ }^{6}$ Only the person with the highest status in the household serves to determine the socio-economic position of the household and all its members.

\section{What form should an instrument for cross-national comparative survey research take?}

Social science survey research is interested in the socio-economic status and occupational prestige of the target person. Moreover, like researchers in the field of social medicine, social scientists are interested in describing occupational activity as a means of analysing social change or health conditions at work, for example. In order to be able to do this, they not only need to know what the respondent's main job is but also whether this job dominates the person's everyday life and, thus, determines his or her social status. The fact that the European Social Survey (ESS) defines economic activity via the question "... did you do any paid work (of an hour or more) in the last seven days?" (ESS 2002: Question F9; ESS 2008: Question F9), renders a social scientific interpretation difficult. The ESS survey measures only the number of hours worked in the respondent's main job, while side jobs are disregarded. Hence, it does not succeed in determining the number of hours worked in all occupational activities. However, all economically active respondents, including the marginally employed persons defined above, are asked to give details of their main job (ESS 2002: Questions F21-F23; ESS 2008: Questions F24-F26). In this way, the occupation can be coded into ISCO-COM ${ }^{7}$ (Elias and Birch 1994).

Like the ESS, the International Social Survey Programme (ISSP) asks whether the respondent is economically active; it then narrows its focus to the 'main job' and records 'any paid work' of an hour or more in the reference week; and then

6 In general, the probability that the reference person determines the socio-economic status of the entire household is 1 divided by the number of adult household members.

7 ISCO-COM is the version of ISCO used by the national statistical offices of the European Union. 
asks for the details of the respondent's occupational activity in order to be able to code it into ISCO. Once again, the definition of 'work' is oriented towards the ILO definition: "By work we mean doing income-producing work, as an employee, self-employed or working for your own family's business, for at least one hour per week" (ISSP 2009, WORK variable).

In the ESS and ISSP surveys it is possible to define the minimum number of hours that must be worked in order that a job should qualify as the 'main job'. Nonetheless a question along these lines leads to attribution problems. In the ESS, the full-time and part-time work of most economically active respondents can be captured in such a way that they can be assigned a socio-economic status on the basis of their occupational activity. However, in the first two ESS questions about economic activity we find two different definitions. First, respondents are asked which response category best describes what they have been doing for the last seven days (ESS 2008: Question F8a). Besides the 'in paid work' category (with several supplements in brackets, which is problematical in an interview situation because text in brackets is often not read out), there are two 'unemployed' categories, a 'community or military service' category, and four categories for the description of those who are 'not economically active'. In the next question (ESS, 2008: Question F9), the definition of economic activity changes. Not only is the question now limited to the 'currently active population' as defined by the ILO (ILO 1982: 2), but also the definition of economic activity is that used in the labour force framework (ILO 1982; United Nations Economic Commission for Europe 2006: 54): "any paid work (of an hour or more)".

In order to determine the occupational status, the category that determines this status must first be identified. However, the respondent's occupational status in the sociological sense is not determined only by the 'paid work [done] in the last seven days'. Nor is the occupational status adequately captured by the criterion 'paid work of one hour or more'.

Hence the concept of economic activity must be defined for all concerned (including the respondent) in the first stage of the survey. We define 'economic activity' as work for pay, i.e. wage or salary (in the case of employees), profit (in the case of self-employed persons), or family gain (in the case of contributing family workers). It makes sense to differentiate here between full-time employment, part-time employment, marginal employment and "not economically active". We define marginal employment as any economic activity that amounts to less than half a normal working day in the particular country and/or sector. In a second question, all those persons who have classified themselves as 'not economically active' must be assigned to a response category with which their labour status can be identified. The categories in question are the four ESS categories that identify the groups who are 'not economically active' ('in education', 'permanently sick or disabled', 'doing housework', 'looking after children or other persons', 'other reason'). However, these are also the categories that describe temporary labour-status situations (e.g. retraining or parental leave), 
or statuses that are based on national labour market measures such as preretirement or semi-retirement schemes.

If the respondent is economically active, his or her professional status (also referred to as employment status), the number of jobs pursued and the number of hours worked in each job must then be recorded. This is necessary because in order to determine socio-economic status one must identify the occupational activity that characterises the target person.

A further step entails describing in detail the current or previous occupational activity that has been identified as the one that determines the person's status. This detailed description includes the type of activity pursued. If the person is selfemployed, the enterprise size is recorded; if the person is an employee, his or her professional status is ascertained; and to assess the level of autonomy within the job, employees are asked whether they have supervisory responsibilities.

The socio-economic status of the entire household can be ascertained with the help of the professional status and the description of the occupational activity of the main earner. If one assumes that the household member with the highest status determines the socio-economic status of the entire household, then this information is indispensable. The susceptibility to error arising from the fact that the respondent replies on behalf of the main earner (proxy response) is less grave than the assignment of an incorrect socio-economic status to the household based on the data of a respondent who is not the main earner (Warner 2009: 103ff).

The ILO definition of economic activity is not introduced until the end of the battery of questions about labour status and occupational activity, when respondents are asked: "Did you do any work for pay, profit or family gain for at least one hour during the last week?". The goal of the survey is the sociological concept of socio-economic status rather than the economic concept of labour status. Hence, the introduction of the ILO concept at an earlier stage could confuse the respondents.

\section{Major principles of a proposed survey instrument and its application}

The aims of the proposed instrument for the measurement of socio-economic status and personal labour market situation are threefold: a) to collect all the information needed to determine respondents' socio-economic status, b) to capture respondents' personal labour market situation as precisely and comprehensively as possible with the help of a small number of questions, and c) to ensure comparability with the reference data of the national statistical offices by incorporating the ILO's labour force concept.

The proposed survey instrument comprises eight steps: 
1) First, we determine whether the respondent is working, and, if yes, how many hours a week (rough categories) (Question 1).

2) Then, the labour status of those respondents who are not working or who are marginally employed is ascertained using relatively detailed categories (Question 2).

3) If the target person is unemployed, seeking employment, or undergoing retraining, they are asked if they would be available for work in the short term (Question 3).

4) The main focus of the fourth step is the professional status of the respondent (Question 4). In the case of persons in employment - be they full-timers, substantial part-timers or only marginally employed (Question $6)$ - the type of employment and the number of jobs held are determined (Question 5). If the respondent has several jobs, the number of hours worked in each job is ascertained (Questions 7 and 9), and the type of work performed in each job is identified (Question 8). And finally, the normal number of hours worked is recorded (Question 10).

5) Those target persons who are no longer in employment are asked whether they worked full- or part-time in the past (Question 11).

6) In the case of respondents who are currently or were previously in full- or part-time employment, a description of their main job is obtained in order to be able to code it into ISCO-88 or ISCO-08 (Questions 12). Then their occupational category is determined on the basis of job type (Question 13) and the level of autonomy within the job (Questions 14, 15, 16 for different groups of jobs). The final information required in this step is whether the respondent is or was responsible for supervising other employees (Question 17).

7) Step seven entails finding out whether the respondent is the main earner in the household (Question 18). If this is not the case, the occupation, occupational category, and supervisory responsibilities of the main earner must be ascertained (Questions 19 to 24). This additional focus on a second person in the household - the main contributor to the household income is necessary in order to ascertain the household's socio-economic status because the person with the highest status also influences the status of the other household members.

8) Finally, in Question 30, respondents are asked the question that is central to the ILO labour force concept: "Did you do any work for pay, profit or family gain for at least one hour during the past week?" If the answer is "no", they are asked to give the reason for this inactivity, even if it was only temporary (Question 31).

The question wording, the sequence of questions and the routing through the questionnaire are published in Hoffmeyer-Zlotnik and Warner 2011: 55-63. 


\section{Conclusion: Labour status as a social science instrument}

In contrast to other cross-national comparative surveys that are oriented towards the ILO concept, the instrument presented here does not begin with the question central to that concept. In view of the fact that it is a social science instrument, economic activity is first measured in broad time categories in order to filter out the groups in which this activity is the central variable for the determination of socio-economic status. Compared to the ILO concept, this leaves the respondents more room for subjective definition. This definitional leeway is necessary in order to separate relevant data from irrelevant information. It is not until the end of the questionnaire that the ILO concept of labour force status is introduced in order to maintain comparability with national statistical office data and European reference statistics (see matrix in Appendix).

Researchers who wish to extend the battery of questions on economic activity, for example by asking about the sector in which the person works, can find suitable instruments on Eurostat's metadata server RAMON ${ }^{8}$.

\section{Acknowledgement}

We would like to extend our thanks to the translator, Miriam Geoghegan.

\section{References}

[1] Duncan, O.D. (1961): A socioeconomic index for all occupations. In Reiss, A.J. jr. (Ed.): Occupations and Social Status, 109-138. New York: Free Press of Glencoe.

[2] Elias, P. and Birch, M. (1994): Establishment of Community-Wide Occupational Statistics ISCO (88) COM. A Guide for User. Coventry: IER, University of Warwick.

[3] European Commission, Eurostat (1995): European System of Accounts, ESA 1995.

http://circa.europa.eu/irc/dsis/nfaccount/info/data/esa95/en/een00000.htm [01 March 2011].

[4] European Commission, Eurostat (2009): EU Labour Force Survey Database. User Guide. Directorate F: Social Statistics and Information Society. Unit F2: Labour Market. Last update: 2 November 2009.

\footnotetext{
${ }^{8}$ http://ec.europa.eu/eurostat/ramon/index.cfm?TargetUrl=DSP_PUB WELC [01 March 2011]
} 
http://circa.europa.eu/irc/dsis/employment/info/data/eu_lfs/LFS_MAIN/LFSu serguide/EULFS_Database_UserGuide_2009.pdf [accessed 01 March].

[5] European Commission, Eurostat (2011): RAMON. Eurostat's Metadata Server http://ec.europa.eu/eurostat/ramon/index.cfm?TargetUrl=DSP_PUB_WELC [01 March 2011].

[6] European Social Survey (ESS), http://www.europeansocialsurvey.org/ [01 March 2011].

[7] European Social Survey (2002): Source Questionnaire (Round 1, 2002/3). ESS DOCUMENT DATE: 01-08-02.

[8] European Social Survey (2008): Source Questionnaire (Round 4, 2008/9). ESS DOCUMENT DATE: 08-08-08.

[9] Ganzeboom, H.B.G., De Graaf, P.M., Treiman, D.J., and de Leeuw, J. (1992): A standard international socio-economic index of occupational status. Social Science Research, 21, 1-56.

[10] Ganzeboom, H.B.G. and Treiman, D.J. (1996): Internationally comparable measures of occupational status for the 1988 International Standard Classification of occupations. Social Science Research, 25, 201-239.

[11] Ganzeboom, H.B.G. and Treiman, D.J. (2003): Three internationally standardised measures for comparative research on occupational status. In Hoffmeyer-Zlotnik, J. H.P. and Wolf, C. (Eds.): Advances in Cross-National Comparison. A European Working-Book for Demographic and SocioEconomic Variables, 159-193. New York: Kluwer Academic / Plenum Publisher.

[12] Hauser, R.M. and Warren, J.R. (1997): Socioeconomic indexes for occupations: A review, update and critique. Sociological Methodology, 27, 177-298.

[13] Hoffmeyer-Zlotnik, J.H.P and Warner, U. (2011): Measuring Occupation and Labour Status in Cross-National Comparative Surveys. GESIS Series, Volume 7. Bonn: GESIS.

[14] Hussmanns, R., Mehran, F., and Verma, V. (1990): Surveys of Economically Active Population, Employment, Unemployment and Underemployment: An ILO Manual on Concepts and Methods. Geneva: ILO.

[15] International Labour Organization (ILO) (1982): Resolution Concerning Statistics of the Economically Active Population, Employment, Unemployment and Underemployment. Adopted by the Thirteenth International Conference of Labour Statisticians.

www.ilo.org/public/english/bureau/stat/download/res/ecacpop.pdf

[01 March 2011].

[16] International Labour Organization (ILO) (1990): International Standard Classification of Occupations, ISCO-88. Geneva: ILO. 
http://www.ilo.org/public/english/bureau/stat/isco/isco88/index.htm [01 March 2011].

[17] International Labour Organization (ILO) (2008): International Standard Classification of Occupations.

http://www.ilo.org/public/english/bureau/stat/isco/isco08/index.htm

[01 March 2011].

[18] International Labour Organization (ILO) (1990): Surveys of Economically Active Population, Employment, Unemployment and Under Employment: An ILO Manual on Concepts and Methods. Geneva: ILO.

[19] International Social Survey Programme (ISSP), http://www.issp.org [01 March 2011].

[20] International Social Survey Programme (ISSP) (2009): Demographic Methods Group (DMG): ISSP Background Variables Guidelines Version of 2009-0827, unpublished.

[21] Leiulfsrud, H., Bison, I. and Solheim, E. (2010): Social Class in Europe II. The European Social Survey 2002-2008. Department of Sociology and Political Science Norwegian University of Technology and Science, Norway and Department of Sociology and Social Research University of Trento, Italy. http://www.svt.ntnu.no/iss/ESSReport2010.pdf [01 March 2011]

[22] Mayer, K.U. (1979): Berufliche Tätigkeit, berufliche Stellung und beruflicher Status - empirische Vergleiche zum Klassifikationsproblem. In Pappi, F.U. (Ed.): Sozialstrukturanalysen mit Umfragedaten, 79-123. Königstein/Ts.: Athenäum.

[23] Nam, C.B. and Powers, M.G. (1983): The Socioeconomic Approach to Status Measurement. Houston: Cap and Gown Press.

[24] Nam, C.B. and Boyd, M. (2004): Occupational status in 2000. Over a century of census-based measurement. Population Research and Policy Review, 23, 327-358.

[25] North, C.C. and Hatt, P.K. (1947): Jobs and occupations: A popular evaluation. Opinion News, 9, 3-13.

[26] Rengers, M. (2004): Das international vereinbarte Labour-Force-Konzept. Wirtschaft und Statistik, 12/2004, 1369-1383.

[27] Treiman, D.J. (1977): Occupational Prestige in Comparative Perspective. New York: Academic Press.

[28] United Nations Economic Commission for Europe (2006): Conference of European Statisticians Recommendations for the 2010 Censuses of Population and Housing. New York and Geneva: United. Nations. http://www.unece.org/stats/publications/CES_2010_Census_Recommendation s_English.pdf [01 March 2011]. 
[29] United Nations Statistics Division (1993): The System of National Accounts 1993. http://unstats.un.org/unsd/nationalaccount/sna1993.asp

[01 March 2011].

[30] Warner, U. (2009): Die Messung von Einkommen in der international vergleichenden Umfrageforschung. Mannheim: Forschung Raum und Gesellschaft e.V.

\section{Appendix}

Table 1: From the proposed survey instrument to the ILO concept of Labour Force.

\begin{tabular}{|c|c|c|c|c|c|c|c|c|c|c|}
\hline Q1=1,2 & \multicolumn{10}{|c|}{ Q1=3,4 (employed less than 15 hours, not employed) } \\
\hline & \multicolumn{3}{|c|}{ Q2= pupil, student } & \multicolumn{2}{|c|}{ Q2= unemployed } & \multirow{4}{*}{$\begin{array}{c}\begin{array}{c}\text { Q2= } \\
\text { military, } \\
\text { social } \\
\text { service }\end{array} \\
\downarrow\end{array}$} & \multicolumn{3}{|c|}{ Q2= retired } & \multirow{4}{*}{$\begin{array}{c}\text { all other } \\
\text { Q2 } \\
\\
\downarrow \\
\downarrow\end{array}$} \\
\hline Q4 - Q24 & Age $<15$ & \multicolumn{2}{|c|}{ Age $\geq 15$} & Q3=yes & Q3=no & & \multicolumn{2}{|c|}{ Age $<75$} & Age $\geq 75$ & \\
\hline$\downarrow$ & I & $\downarrow$ & । & & & & $\downarrow$ & $\downarrow$ & & \\
\hline Q30=yes & $\downarrow$ & Q30=yes & Q30=no & $\downarrow$ & $\downarrow$ & & Q30=yes & Q30 $=$ no & $\downarrow$ & \\
\hline $\begin{array}{c}\mathrm{ILO}= \\
\text { employed }\end{array}$ & $\begin{array}{c}\text { ILO= } \\
\text { person } \\
\text { less than } \\
15 \text { years } \\
\text { old }\end{array}$ & $\begin{array}{c}\text { ILO= } \\
\text { employed }\end{array}$ & $\begin{array}{c}\mathrm{ILO}= \\
\text { inactive }\end{array}$ & $\begin{array}{c}\mathrm{ILO}= \\
\text { unemployed }\end{array}$ & $\begin{array}{c}\mathrm{ILO}= \\
\text { inactive }\end{array}$ & $\begin{array}{c}\text { ILO= } \\
\text { comp. } \\
\text { military } \\
\text { service }\end{array}$ & $\begin{array}{c}\text { ILO= } \\
\text { employed }\end{array}$ & $\begin{array}{c}\mathrm{ILO}= \\
\text { inactive }\end{array}$ & $\begin{array}{c}\mathrm{ILO}= \\
\text { inactive }\end{array}$ & $\begin{array}{c}\text { ILO= } \\
\text { employed }\end{array}$ \\
\hline
\end{tabular}

Q1: Are you currently ....1: employed full time with a weekly working time of 35 hours or more 2: employed part time with a weekly working time of 15 to 34 hours 3: employed part time or on an hourly basis with a weekly working time of less than 15 hours or 4: not employed INT.: 'Employed' refers to work for pay (wage, salary, fee), profit (in the case of self-employed persons), or family gain (in the case of contributing family workers)

Q2: Are you currently ...1: undergoing vocational training (apprenticeship, secondary-level vocational school, post-secondary vocational school, school for master craftspersons, third-level vocational college, work placement, trainee programme etc.) 2: attending a general education school or a university 3: in a retraining programme 4: unemployed, seeking employment 5: a homemaker (doing housework, looking after children or other persons) 6: on maternity or parental leave 7: a conscript in compulsory military or community service, doing a voluntary social or ecological year etc. 8: in early retirement 9: retired 10: in the work-free phase of pre-retirement part-time work for older employees 12: unable to work because of sickness or disability 13: economically inactive for other reasons...

Q3: If you were offered a job today, could you start work within two weeks? 1: yes 2: no

Q4 to Q24: questions on employment, work hours, occupation and the main income earner of the household

Q30: Did you do any work for pay, profit or family gain for at least one hour during the last week (as an employee, a self-employed person, or as a contributing family worker)? 